\title{
Fighting the Ignorance: Public Authorities' and Land Users' Responses to Land Subsidence in Indonesia
}

\author{
Erlis Saputra ${ }^{1,2 *}$, Thomas Hartmannn ${ }^{1}$, Annelies Zoomers ${ }^{1}$, Tejo Spit ${ }^{1}$ \\ ${ }^{1}$ Department of Human Geography and Spatial Planning, Utrecht University, Utrecht, The Netherlands \\ ${ }^{2}$ Department of Development Geography, Universitas Gadjah Mada, Yogyakarta, Indonesia \\ Email: *E.Saputra@uu.nl
}

How to cite this paper: Saputra, E., Hartmann, T., Zoomers, A. and Spit, T. (2017) Fighting the Ignorance: Public Authorities' and Land Users' Responses to Land Subsidence in Indonesia. American Journal of Climate Change, 6, 1-21.

https://doi.org/10.4236/ajcc.2017.61001

Received: October 13, 2016

Accepted: February 4, 2017

Published: February 7, 2017

Copyright $\odot 2017$ by authors and Scientific Research Publishing Inc. This work is licensed under the Creative Commons Attribution International License (CC BY 4.0). http://creativecommons.org/licenses/by/4.0/

\begin{abstract}
Land subsidence can have a considerable impact on the socio-economic viability of areas. In urban areas, land subsidence tends to damage buildings and infrastructures gradually, while in rural peat land it slowly destroys vegetation. The damages will worsen since climate change has further implications for the areas affected by land subsidence. In Indonesia, the response to land subsidence varies in different areas in terms of awareness, urgency and action on the part of both public authorities and land users. This paper systematically investigates these varied responses in urban and rural peat land areas. Interviews with experts and surveys of 330 land users in selected sub-districts were conducted and further supplemented by focus group discussions. We found that both the public authorities as well as the land users' responses were considered as of limited value to contest land subsidence. We suggest that the endorsement of land users' response into governmental policies would make a significant difference in improving land subsidence management.
\end{abstract}

\section{Keywords}

Indonesia, Land Subsidence, Land Users, Public Authorities, Response

\section{Introduction}

Land subsidence is a gradual settling or sudden sinking of the earth's surface due to movement of earth materials [1] or an abrupt depression of local ground surface [2]. The relation between land subsidence and urban or rural areas is twofold: first, if land subsidence occurs on urban land, it can severely damage or even lead to the collapse of buildings and damage plantations in rural land. Therefore, these areas are particularly vulnerable to land subsidence. Second, the 
natural consolidation of sediments can be increased by the weight of construction on top of the land [3] [4]. Agricultural expansion and a failure in the plantation system might also worsen the subsidence. Therefore, land subsidence is directly linked with urban and rural development. Addressing this issue is crucial in these areas, particularly in delta and peat land areas.

The Indonesian urban areas of Jakarta and Semarang City suffer from land subsidence at a high level. Not only are they densely settled areas, but the effects of land subsidence are also extreme. Some areas of Jakarta sink about 1 - 15 centimeter per year, while other areas sink up to 20 - 28 centimeter per year [4]. In addition, the rapid population growth in Jakarta of about 136 thousand people per year triggers additional groundwater extraction, which in turn increases land subsidence [3] [4]. Semarang City experiences land subsidence of about 8 - 11 centimeter per year [5], caused by a combination of alluvium soil consolidation, massive groundwater extraction and a heavy construction load [6] [7]. In both cases, the intensive growth of industrial areas, settlements and population, leads to increased demand for clean water extracted with confined aquifers, and accelerates land subsidence [3] [8]. In addition, the combination of the land subsidence and sea level rise in the coastal area further increases the area's exposure to land subsidence, since the rise of the sea level renders coastal areas more unstable. Besides the urban areas, the rural peat land of Indragiri Hilir also suffers from land subsidence at a speed of about $4-6$ centimeter per year. The land subsidence on the peat land area is caused by desiccation, consolidation, water erosion and bio-chemical oxidation [9] [10]. An intensive expansion of infrastructures and farming on the peat land also accelerates the subsidence in Indragiri Hilir. The subsidence further worsens due to intensive drainage on peat land. The use of an intensive drainage system during agricultural activities has led to large carbon losses due to the oxidation of peat, which has triggered subsidence [10] [11] [12]. Population growth and their activities create a higher demand for space. Many environmental problems depend on the population distribution [13]. Since the capacity is limited and the population growth is constant, the land subsidence seems to be getting worse. These three cases illustrate the need to address land subsidence.

In order to reduce and prevent land subsidence, adaptation and mitigation are potential options for public authorities and land users. McGranahan et al. [14] argue that, in order to reduce disaster risk related to climate, the approaches of adaptation and mitigation might be combined. Similar to climate change, a long-term process of land subsidence might require a consideration of the actors involved. Hartmann and Spit [15] argue that the understanding of climate problems might support the implementation of adaptation strategies. Since this is a process of a considerable time frame, the climate issue at its root receives too little attention from local decision makers. Proper choice of adaptation should reduce consequences [16]. The public authorities should design policies that can alleviate problems, such as reducing groundwater extraction, artificially recharging aquifer systems and designing spatial zoning regulations to prevent 
future problems. Ye et al. [17] showed that, by controlling groundwater withdrawal, land subsidence in Shanghai decreased to an average speed of 5.5 millimeter per year. Therefore, these detailed water-related policies must be accommodated in urban planning policies in order to increase the capacity of the adaptation [18].

How do actors in urban and rural peat land areas address land subsidence? In this paper, our main goal is to assess actors' responses to land subsidence. In particular, we focus on the responses of public authorities and affected land users in urban and rural peat land areas. Using the different characteristics of urban and rural peat land, land subsidence management in these different areas can be explored and compared. We assessed to what extent these actors are aware of the risk of land subsidence (awareness), to what extent they perceive an urgency to act (urgency) and what they actually do (action). This three-stage model of awareness, urgency and action has previously been used to show indicators in responding to changing environmental conditions, such as climate change [15]. This scheme is used to depict the status of public policies with respect to land subsidence.

We will start by describing the response in Disaster Risk Management phases, analytical thinking and indicators used in assessing the response to land subsidence, and status of land subsidence to prove the importance of addressing the issue. Next, we will explain the response of public authorities and land users to land subsidence in each case study area.

\section{Response to Land Subsidence in Disaster Risk Management}

Disaster Risk Management (DRM) refers to a framework of reducing disaster risk by including management perspectives that combine prevention and preparedness along with the response. Its purpose is to reduce possible risk factors and to prepare a response to them [19]. It includes actions taken before (predisaster), during (disaster) and after a disaster (post-disaster) as a cycle.

Regarding land subsidence, most of the responses and efforts are taken in a pre-disaster phase while some of them happened in the post-disaster phase. The pre-disaster phase includes risk identification and mitigation as well as preparedness [20]. Its aim is to strengthen households' capacity and resilience in protecting their livelihoods [19]. The role of public authorities in this phase is to respond to and mitigate the risk. Political will and updated plans are required during this phase [20]. On the other hand, households' capacity to protect themselves by avoiding and mitigating hazards must be increased, and strategies to cope with the problems must be realized [19]. In the post-disaster phase, the focus is on recovery and rehabilitation of damages.

In land subsidence management, the response of actors, especially during risk identification, is crucial. Relevant actors must have knowledge about current and forthcoming conditions to respond to a disaster successfully [21]. The response should be pursued by public authorities and affected land users. The land users' 
ability to respond is important since they are a prime component in the disaster mitigation process due to their knowledge of recent problems.

Response includes three stages: awareness, urgency and action [15]. Awareness is the knowledge gathered from interactions between people and the environment, which must be updated for different situations. Awareness is crucial for success in disaster management [22] because it is used to assess the degree to which public authorities and land users recognize existing problems. It can be identified from government's initiative to design subsidence-related plans [23]. There are four components they must be aware of: the riskiness of the area they live in, the status of the land subsidence, different ways to solve problems and action to prevent upcoming problems.

The land subsidence issue must be brought to the awareness of public authorities and land users with a sense of urgency to emphasize its importance and make sure actions taken reach the policy level. To deal with disaster phenomena, Blaikie et al. [24] argued that the phenomena must be included in the making of mainstream policy and practice. To reflect a sense of urgency, public authorities must accommodate the phenomena of land subsidence in their policies. Political limitations need to be modified to allow people who are not formal authorities to be involved in designing the policy and in implementing it.

Realizing action from awareness and urgency policies is challenging in land subsidence management, as it has complex procedures. Tang et al. [25] argued that any actions should consider a comprehensive awareness, complete an analysis, and adopt concrete action policies to reduce the problems. Gaillard and Mercer [26] argued that the action must integrate an assessment of risk based on scientific and local knowledge, and must establish dialogue between outside and inside actors. Action determined by multilevel actors and sectors will help increase resilience in a disaster [27] [28].

\section{Empirical Evidence from Three Case Study Areas}

This paper explores three case study areas in Indonesia: the urban areas of Jakarta and Semarang City and the rural peat land of Indragiri Hilir (Figure 1). The case studies all experience land subsidence issues, but public authorities (local governments) and land users respond to it differently. The responses differ in the measures undertaken by land users and in terms of policy actions.

In this research, several empirical research methods were combined. To reveal responses to land subsidence in the case study areas, governmental and nongovernmental reports have been analyzed and complemented by interviews with officers and academics. To analyse land users' responses to land subsidence, surveys of 330 land users in twelve selected sub-districts (kecamatan) of affected areas have been conducted; all this was further complemented by focus group discussions. Respondents to the survey were selected based on a combination of three considerations: highest speed of land subsidence, area characteristics (urban and peat land areas) and land use (settlements, industrial or plantation area). Focus group discussions were conducted with community leaders from 


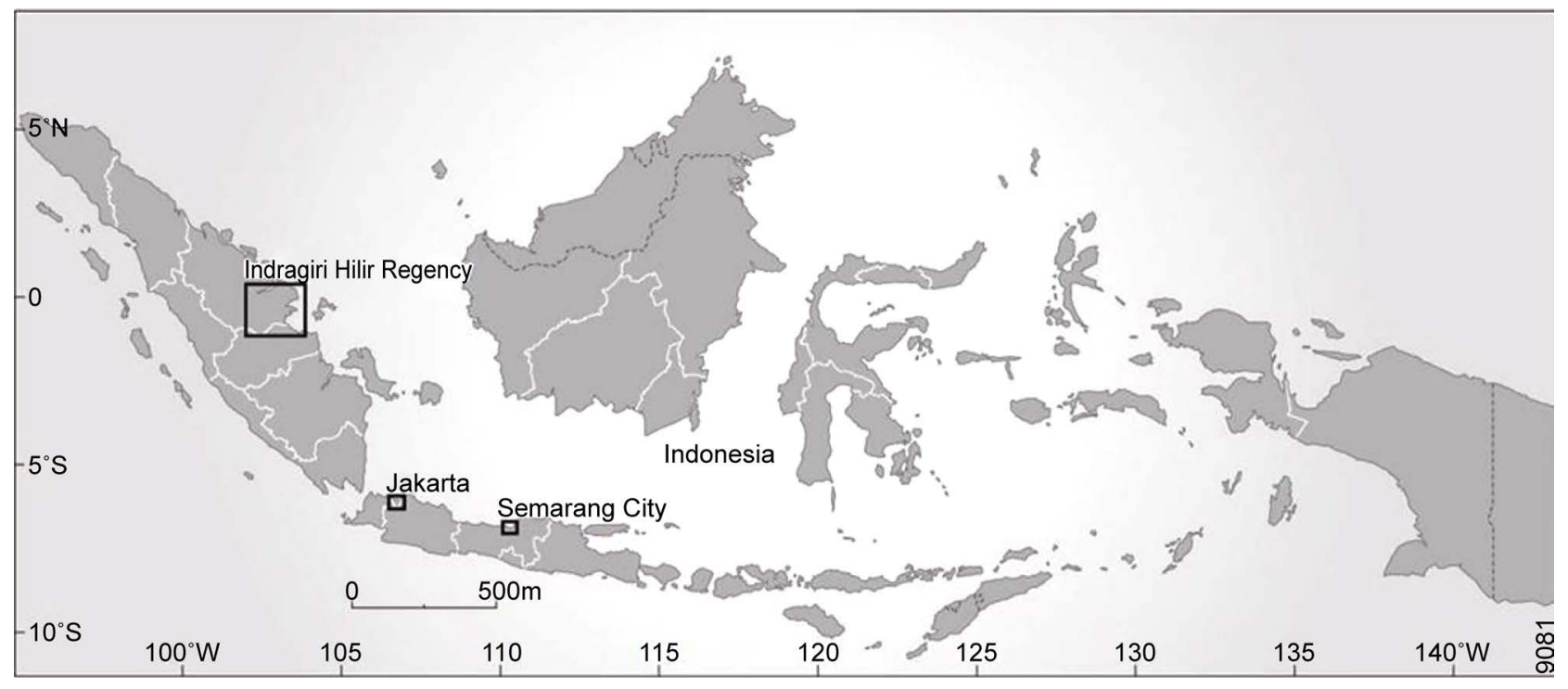

Figure 1. Location of case study area.

affected and surrounding areas to determine the community's knowledge of land subsidence.

\section{Analytical Thinking and Indicators}

The awareness of land subsidence is linked to individual people's personal experiences facing the problem. These experiences cause each individual to perceive the problem in a different way and influence people's perception regarding the urgency of the problem. However, the sense of urgency depends on people's perspective on the problem [29]. Problems that are perceived as a threat to daily life lead people to action. On the contrary, if the problems seem manageable, the affected persons' concern tends to wane. Therefore, action is comprised of a combination of individual awareness and sense of urgency. There is no sense of urgency when people are unaware of the problem, and there is no action if the problem seems non-essential to solve. This concept will guide our analysis of public authorities' and land users' response to land subsidence as found with the help of the above described research tools.

We assessed the response of public authorities and land users in different ways. Public authorities' response is assessed according to the response phases laid out by Hartman and Spit [15]. We develop indicators to assess the response qualitatively (see Table 1). The awareness of the public authorities contains knowledge of land subsidence, i.e., triggers, speed and impacts. A number of legalized policies related to land subsidence, such as water usage, spatial and disaster management planning and land use information, indicate the urgency. Finally, the action is assessed by looking at adaptation and mitigation actions and their effectiveness. The land users' awareness is assessed in terms of their knowledge of the terms, triggers and speed of land subsidence on their land. We then built an urgency indicator measured by the range of time taken to respond. We presume that the more time land users take to respond to land subsidence, the 
Table 1. Response indicators.

\begin{tabular}{lll}
\hline Response level & \multicolumn{1}{c}{ Public authority } & \multicolumn{1}{c}{ Land user } \\
\hline \multirow{2}{*}{ Awareness } & $\begin{array}{l}\text { Knowledge of land subsidence (term, trigger, and speed) } \\
\text { Distribution and designed map identification }\end{array}$ & Knowledge of land subsidence (term, trigger, and speed) \\
& Water-related policies & Range of time to respond after awareness \\
Urgency & $\begin{array}{l}\text { Spatial and disaster management plans } \\
\text { Land use information }\end{array}$ & \\
Action & Adaptation & Adaptation \\
& Mitigation & Mitigation \\
\hline
\end{tabular}

less urgent the problem in their perception. Lastly, the action is assessed by examining ways and means of self-adaptation and mitigation of upcoming subsidence.

\section{Causes and Impacts of Land Subsidence}

Land subsidence in the case study areas was not only naturally-induced, but also was caused by human-induced processes. For instance, wrong policies and human activities in some of the affected areas stimulated the land subsidence. The land subsidence in the urban coastal area of Jakarta and Semarang City was also triggered by coastal reclamation, according to community representatives. The reclamation increased the surface material load and then accelerated the subsidence. In the rural peat land, Indragiri Hilir suffers from land subsidence caused by rapid expansion of coconut tree and oil palm plantations. Jaenicke et al. [12] showed that the expansion of plantation areas has released large amounts of carbon into the atmosphere that have triggered peat subsidence. If the oxidation is happened constantly, it will also trigger peat fires and then will contribute to the process of global climate change [30].

Aside from the direct impacts, such as the damage of infrastructure and construction [31] [32], land subsidence has other negative impacts, such as salinization of coastal areas [33] [34], degradation of groundwater and changes to the water system [35]. Land subsidence triggers direct economic loss and external cost incurred in the effort to rehabilitate damaged construction, infrastructure and farmland [36] [37]. Hu et al. [38] revealed that land subsidence in coastal areas caused a huge economic loss. In the peat land, we found that land subsidence at a traditional canal system destroyed cultivated areas. If the damage is continuously happened, it will cause a loss of economic activity and damage natural resources. If the government is not aware of the impacts and approves the plantation investment by cultivating peat land, this might trigger wider land subsidence. Therefore, land subsidence affects the environment in various ways.

Our surveys identified six physical-environmental impacts of land subsidence in urban areas (see Table 2). The table displays the impact percentages, which shows a heavy impact regarding damage to houses and infrastructures or facilities and expansion of the flooding area. According to the table, the land subsidence predominantly affected houses, which comprised more than one-third of 
the total impact in each area. The damages are dominated by the subsided and skewed-houses (see Figure 2). At the same time, combined with the rise of the sea level and climate change, the land subsidence in Semarang City has enlarged the flooded area, threatened coastal settlements and triggered large-scale damage of infrastructures. The Department of Marine and Fisheries of Semarang City clarified that land subsidence stimulated coastal inundation to the extent of a strip between 0.738 kilometers and 5.475 kilometers wide. Along with the inundation, land subsidence initiated coastal erosion from 101 meters to 2540 meters in length.

Land subsidence not only affected the urban areas, but also the rural peat land. Our surveys of peat land in Indragiri Hilir found that land subsidence ruined houses and infrastructures (see Table 3). Mostly, the damage led to leaning houses in capital cities and rural areas. The subsidence also destroyed plantations, such as coconut tree, oil palm and timber (see Figure 3). Local farmers indicated that almost half of total coconut tree plantations were damaged. Another notable impact is the expansion of the flooded area. In a high rain season, such as December, sinking areas will be exposed to a higher level of annual tidal inundation (local name: pasangkeling). Along with the subsidence, this leads to further damage to houses, infrastructures, facilities and coconut tree plantations.

Table 2. Physical-environmental impacts of land subsidence in urban areas.

\begin{tabular}{lcccc}
\hline \multirow{2}{*}{ Impacts } & \multicolumn{2}{c}{ Jakarta } & \multicolumn{2}{c}{ Semarang city } \\
\cline { 2 - 4 } & Number of cases & Percentage & Number of cases & Percentage \\
\hline Damage to infrastructures/facilities & 54 & $29.8 \%$ & 72 & $30.6 \%$ \\
Damage to houses & 73 & $40.3 \%$ & 87 & $37.0 \%$ \\
Cracks in permanent constructions & 3 & $1.7 \%$ & 56 & $7.2 \%$ \\
Expansion of flooding area & 45 & $24.9 \%$ & 0 & $23.8 \%$ \\
Lowered groundwater elevation & 4 & $2.2 \%$ & 3 & $0 \%$ \\
Increased inland seawater intrusion & 2 & $1.1 \%$ & $1.3 \%$ \\
Total & 181 & $100 \%$ & 235 & $100 \%$ \\
\hline
\end{tabular}

Source: questionnaire analysis (2016).

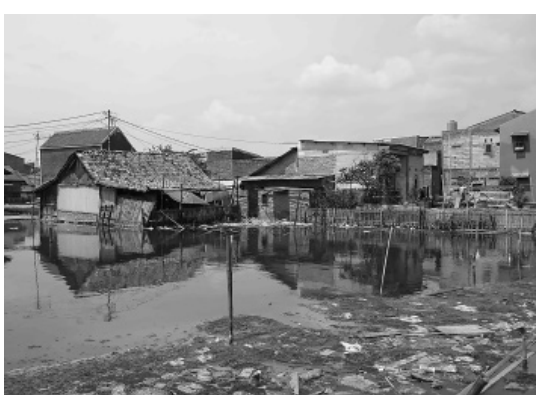

(a)

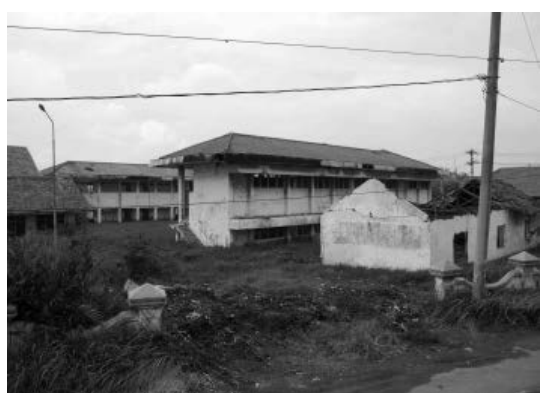

(b)



(c)

Figure 2. Physical-environmental impacts of land subsidence in urban areas (2016). (a) Inundated settlement (Jakarta); (b) Subsided school (Semarang City); (c) Subsided house (Semarang City). 
Table 3. Physical-environmental impacts of land subsidence in rural peat land.

\begin{tabular}{lcc}
\hline \multicolumn{1}{c}{ Impacts } & \multicolumn{2}{c}{ Indragiri Hilir } \\
\cline { 2 - 3 } & Number of cases & Percentage \\
\hline Damage to infrastructures/facilities & 39 & $19.0 \%$ \\
Damage to houses & 75 & $36.6 \%$ \\
Cracks in permanent constructions & 1 & $0.5 \%$ \\
Expansion of flooding area & 9 & $4.4 \%$ \\
Damage to coconut plantations & 46 & $22.4 \%$ \\
Damage to timber plantations & 6 & $2.9 \%$ \\
Damage to oil palm plantations & 29 & $14.1 \%$ \\
Total & 205 & $100 \%$ \\
\hline
\end{tabular}

Source: questionnaire analysis (2016).



(a)

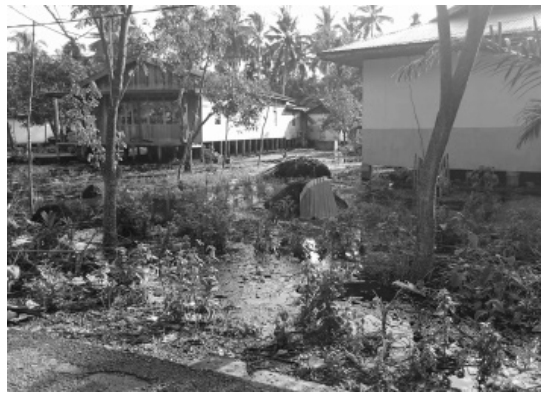

(b)

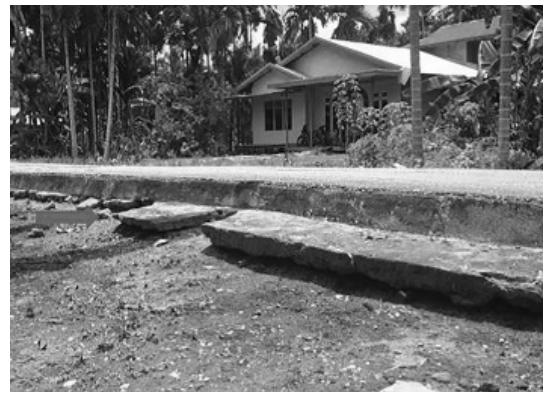

(c)

Figure 3. Physical-environmental impacts of land subsidence in rural peat land (2016); (a) Damaged plantation (Indragiri Hilir); (b) Flooded environment (Indragiri Hilir); (c) Damaged infrastructure (Indragiri Hilir).

Since subsidence is a serious problem in several locations, the public authorities and land users must be knowledgeable concerning causes and impacts. The awareness of public authorities is clearly important in designing proper policies. On the other hand, the land users' awareness is necessary for their own protection. Awareness of predictable hazards might effectively increase peoples' participation in disaster management [39] and their safety [40]. Thus, awareness in managing land subsidence will lead to a sense of urgency and action.

\section{Public Authorities' Response on Land Subsidence}

Public authorities' responses to land subsidence vary depending on their willingness and capacity to acknowledge problems and to respond. Correct actions are still not often taken in both urban and rural peat land areas because response types have been too varied.

\subsection{Jakarta}

\subsubsection{Awareness}

The Jakarta Government gathered information regarding the status of land subsidence from academics, researchers and non-governmental organizations, as 
well as through self-measurement. As a part of this awareness, the government designed and evaluated maps of land subsidence distribution. The government's awareness was also reflected in Spatial Master Plan Regulation, Article 77, where information of the affected areas had already been published.

\subsubsection{Urgency}

Water-related policies and Spatial Planning are seen as indirect policies that can manage the land subsidence. Regarding water-related policies, the Jakarta Government legalized DKI Jakarta Regulation No. 8/2007 and No. 17/2010. Regulation No. 8/2007, Article 23, Section 1 and Section 2, state that every extraction activity of groundwater and surface-water for commercial purpose must be based on governor permits. Moreover, the regulation No. 17/2010 regulates a higher tax for groundwater usage in order to limit instances of exploitation. The government then launched the "zero deep well" program to limit groundwater usage by industry and households and move toward a piped water system.

The government also released DKI Jakarta Regulation No. 1/2012 about Spatial Master Plan and No. 1/2014 about the Spatial Detail Plan and Zoning Regulation. These policies indicate that all of the areas have already been shaped on certain activities and intensity. The Spatial Master Plan indicates that Jakarta will decrease disaster risk through adaptation and mitigation activities (Article 6, Section 8). In Article 42, land subsidence is pointed out as a consideration that led to an effort to conserve water resources. Then, Article 77 details areas impacted by land subsidence. Section 4 of Article 44 regulates zero delta development and expanded dike development in areas prone to flooding. Zoning Regulations of Jakarta were designed based on carrying capacity of the zones. Every zone contains regulations, such as incentive mechanism, prohibited development areas and prerequisites to develop the zones. However, this regulation still contains an ambiguous plan. For instance, Kamal Muara was designed as a metro area, but it was also designated as a special area where resources to prevent inundation and flooding will be allocated.

\subsubsection{Action}

In order to adapt to land subsidence, the Jakarta Government launched programs to limit land users' vulnerability by maintaining drainage, lifting up houses and settlement infrastructures and providing water pumps in inundated areas. The government seems more focused on mitigating: building giant sea walls, converting the use of groundwater into piped water for industries, constructing injection wells, monitoring the subsidence and planting "biopori holes". One of the mitigation efforts to deal with flooding due to land subsidence and the rise of sea levels is a mega project of National Capital Integrated Coastal Development (NCICD). However, the government must consider that this project might increase the water level in drainage systems because of the boundaries in its downstream area. They must also consider possible rejection from people living in the coastal settlements as the project widens the inundation areas. 
To limit the use of groundwater, the government restricts industries from extracting unconfined aquifers of groundwater, but people are allowed to extract it in a limited amount. Regarding land utilization, zoning regulations are used to prevent activities that might accelerate the subsidence in affected areas. The government collected peoples' needs and delivered plans using electronic or printed media, public discussion (Musrenbang), workshops and focus group discussions. For land users, the government developed a website containing spatial detail plans and zoning regulations that can be accessed by anyone. The government disseminates land allocation and development rules by revealing this information to the public.

\subsection{Semarang City}

\subsubsection{Awareness}

The Semarang City government has already determined land subsidence status in affected areas and related distribution, triggers, and impacts. Affected areas, such as the Tanjung Mas area, have already been prioritized in spatial planning as protected areas, especially in the coastal areas that are influenced by daily tidal inundation.

\subsubsection{Urgency}

The government has designed policies and planning documents based on the status of the land subsidence in certain areas. Regarding water-related policy, the government released Semarang City Regulation No. 8/2011, which decrees a twenty per cent tax for groundwater extraction. The government also released Semarang City Regulation No. 2/2013 about Groundwater Management, which inventories and manages groundwater in the groundwater basin of Semarang City. Article 19 of this regulation states that groundwater conservation is controlled by monitoring and production of wells. Moreover, in Article 22, Section 4 , the government bans people from extracting groundwater in critical zones, for recovery purposes. The government has also legalized Semarang City Regulation No. 14/2011 about the Spatial Master Plan, which designs rules and activities in both protected and previously-built areas. Section 4 of Article 7 requires the erection of coastal dikes and rehabilitation of coastal green areas to protect coastal and inundated settlements. However, in the same article, the government also allocates the coastal areas as reclamation areas, which-according to the local community-caused subsidence due to the increased material load. This regulation also allocates some strategic areas for economic growth in the affected areas. However, it seems that land subsidence is not a strategic issue in planning policies since it is not a priority in any policies in Semarang City.

\subsubsection{Action}

Land subsidence is considered a part of coastal erosion and inundation problems. The government adapts to land subsidence by renovating damaged houses and streets, providing water pumps and lifting up local streets. In 2014, order to reduce flooding, improve the drainage system and deal with clear water problems, 
the government allowed a national project called Integrated Water Resources and Flood Management Project for Semarang. In 2014, Semarang City prioritized projects such as rainwater harvesting and mangrove planting to increase the land users' resilience in the face of land subsidence and other environmental problems. It is expected that by providing clean water for those people, the amount of groundwater extraction could be reduced. However, the influence of these projects on reducing land subsidence is still limited and debatable.

Preventative activities were also put into place by the government, such as building dikes to prevent inundation, minimizing construction load by reconstructing damaged houses using light materials, conserving mangrove ecosystems, designing communal wells and limiting groundwater extraction in affected areas. The government planted mangroves as a sea wall in 2002 that reclaimed half of 1.96 square kilometer of lost fishponds by 2014. In order to disseminate land use information, the government uses electronic and printed media, as well as interactive education gaming to raise awareness and inform people of the government's plans.

\subsection{Indragiri Hilir}

\subsubsection{Awareness}

The government of Indragiri Hilir finds itself only at the beginning of raising such awareness since as they are still in the process of establishing details related to land subsidence. Although the government is aware of the problem in general, distribution maps showing land subsidence are still absent.

\subsubsection{Urgency}

The government instated Indragiri Hilir Regency Regulation No. 21/2010, which regulates a twenty per cent of tax for groundwater usage. However, in Indragiri Hilir where land subsidence is predominantly triggered by the natural consolidation of soil, construction load and plantation activities, this regulation does not really result in decreased land subsidence. People already prefer to use rainwater over groundwater for their daily needs since the quality of groundwater in this area is poor.

Spatial planning policy in Indragiri Hilir depends on spatial planning of the Riau Province. Since the spatial planning of Riau Province has been postponed, we analysed two spatially related policies: the spatial detail plan of Tembilahan (capital city of Indragiri Hilir Regency) and the fast-growing strategic area plan. Article 14 of the Indragiri Hilir Regency Regulation No. 28/2005 about the Spatial Detail Plan of Tembilahan establishes Tembilahan as an area for multi-activity development (i.e., for trading and service, government offices and settlement). In addition, Article 2 of the Indragiri Hilir Regent Regulation No. 55/2014 about the Fast-Growing Strategic Area of Indragiri Hilir declares some areas that are affected by land subsidence to be fast-growing strategic areas. Since the land subsidence in peat land area of Indragiri is also caused by the physical development, allocating the peat land as regional growth area seems problematic and might increase the subsidence. 


\subsubsection{Action}

Even though the government has not yet legalized policies related to land subsidence, they have already taken action to adapt to the problem such as reconstructing damaged streets, but the changes are still limited. In order to prevent inundation, an indirect result of land subsidence, the government has built and rehabilitated gullies around settlements.

Comparing responses between local governments is important in order to design or redesign proper policies based on the level of their response. We found that local governments have already responded to land subsidence, but to varying degrees (see Table 4). The level of awareness on this issue is higher in urban governments than in rural peat land areas, which is reasonable since urban areas are more planned in terms of infrastructure and usually receive more attention in terms of improvements. Land subsidence is not the main concern of governments and is often perceived as a "sleeping disaster", which may explain some of the ignorance concerning this problem. We did not find a single policy released by governments that is solely focused on land subsidence. Ignoring land subsidence as a strategic issue in environmental policies has multiple impacts: governments have less knowledge of land subsidence status, a lowered sense of urgency and an unstructured action plan. Although they have already designed and regulated numerous policies and were supported by the people's involvement, the degree of response is still low and varied (see Figure 4).

Problems concerning response are stipulated. The difference in responses in Jakarta vs. Semarang City is also influenced by their different level autonomy, even though they are in the same area (i.e., urban coastal). Jakarta as a provincial government has autonomy to legalize policies with the only possibility of intervention being from the central government; meanwhile, Semarang City also has autonomy, but must consider the possibility of intervention from both central and provincial governments. Even with the same level of autonomy, the response level between Semarang City and Indragiri Hilir is dissimilar because of factors such as different land utilization (urban and rural peat land) and the respective government's willingness to cope with the problem. In many situations, responding to land subsidence requires a coherence among different governmental bodies that is unfortunately lacking. As a result, proper policies have not been designed or implemented correctly, or are not implemented at all.

\section{Land Users' Response on Land Subsidence}

The degree of awareness among land users regarding land subsidence in urban

Table 4. Level of local government's response to land subsidence.

\begin{tabular}{cccc}
\hline Local government & Awareness & Urgency & Action \\
\hline Jakarta & ++++ & +++++ & +++ \\
Semarang City & ++++ & +++ & ++ \\
Indragiri Hilir & + & + & + \\
\hline
\end{tabular}

Source: Data analyses (2016). 
and rural peat land area is more or less similar (Figure 5). According to the figure below, more than eighty per cent of all land users could explain what land subsidence is. However, even though knowledge is increasing, we found that some of the land users do not ascribe much importance to land subsidence and its impacts. Knowledge about triggers and speed is not as prevalent as an understanding of the basic term land subsidence. In Jakarta and Semarang City alike, land users are even less knowledgeable about the speed of subsidence than about the triggers because they can usually observe the triggers during their daily activities but cannot measure the exact speed of land subsidence. Land users need to pay more attention to the triggers and subsidence speed as this knowledge will greatly affect how well they adapt to and mitigate the effects of land subsidence.

Figure 4 shows that percentage of land users taking action regarding land subsidence in case study areas is quite varied. According to the figure, urban

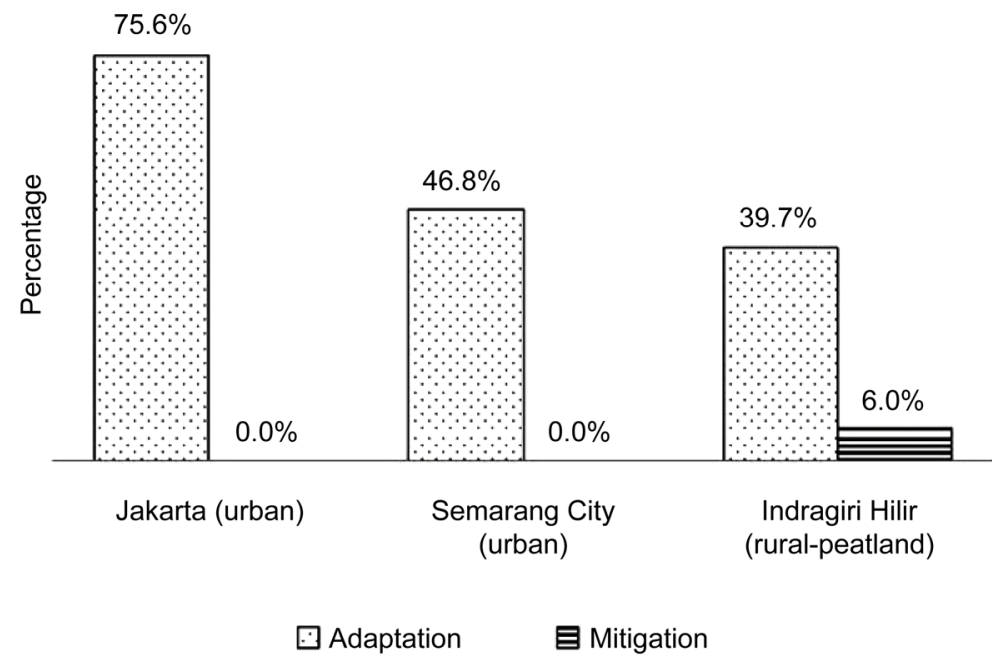

Figure 4. Land users' action on land subsidence.

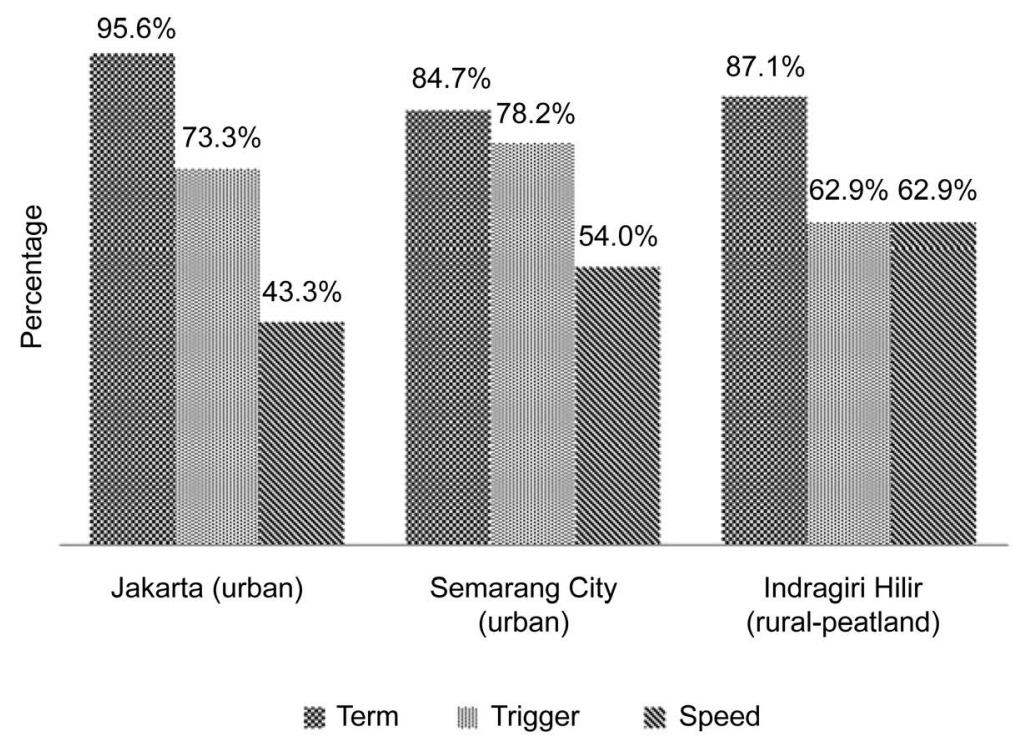

Figure 5. Land users' awareness of land subsidence. 
land users are better adapted than in a rural peat land area but not necessarily better at mitigating the problems. More than three-quarters in Jakarta and almost half of total affected land users in Jakarta and Semarang City have taken various steps toward adapting land subsidence. Meanwhile, in Indragiri Hilir, only about one third of all affected land users have adapted to land subsidence in any way. Comparatively, impacts in urban areas are greater in scale and intensity than in the rural areas and tendencies of how people adapt to the problems are vastly different also. However, only in the rural areas have land users taken pre-emptive steps to mitigate impending problems, though this applies to only six per cent of them. Land users in the urban area have not taken such steps because the local governments have already taken some actions. The government in rural peat land areas have not yet sprang into action.

We also found that the affected land users could potentially contribute and support local governments in solving the problem through self-adaptation and mitigation (see Table 5). The land users in several locations in the urban areas utilized light materials such as wood and batten to rehabilitate the damaged houses in order to reduce the weight-the same method used by governments. Even though the land users in Semarang City did not individually mitigate land subsidence, as a group, they operate communal wells to restrict groundwater exploitation by land users. Land users in rural peat land areas must address some concerns because almost two-thirds of them have not adapted to the current problem. However, from a small group of the land users, we found best practices for mitigation methods. In peat land, the land users utilize wooden pillars in the house foundation to prevent the houses from leaning. They also built houses on stilts (rumahpanggung) to prevent construction loads and cracked floors caused by land creep during the subsidence. Almost all of the affected land users in urban and rural peat land areas are still focusing their efforts on adapting to current problems rather than trying to prevent forthcoming problems.

According to the table, it seems that land users have improperly adapted to land subsidence. Some forms of adaptation might increase the problem if they strengthen the triggers. For instance, in the coastal areas of Jakarta and Semarang City, the land users elevate the house floor to avoid one effect of subsidence,

Table 5. Land users' action to cope with land subsidence.

\begin{tabular}{lll}
\hline \multirow{2}{*}{ Case study area } & \multicolumn{1}{c}{ Action } & \multicolumn{1}{c}{ Adaptation } \\
\cline { 2 - 3 } Jakarta & $\begin{array}{l}\text { Lifting up houses, occupying water pumps during inundation, } \\
\text { and using light materials to rehabilitate damaged houses }\end{array}$ & Using communal wells and bathrooms (as a group) \\
Semarang City & $\begin{array}{l}\text { Lifting up houses and streets, occupying water pumps } \\
\text { during inundation, and using light materials to rehabilitate } \\
\text { damaged houses }\end{array}$ & $\begin{array}{l}\text { Using communal wells and bathrooms, replanting } \\
\text { mangroves, and constructing dikes (as a group) }\end{array}$ \\
Indragiri Hilir & $\begin{array}{l}\text { Constructing gullies around plantation areas to dry out water } \\
\text { from the land, rehabilitating damaged houses and floors, } \\
\text { and replanting the damaged plantations }\end{array}$ & $\begin{array}{l}\text { Constructing and rehabilitating dikes, replanting } \\
\text { mangroves, utilizing wooden pillars in house } \\
\text { foundations, and using light material to build houses }\end{array}$ \\
\hline
\end{tabular}

Source: Field surveys (2016). 
which is inundation. In the short term, this seems to solve the problem, but, in fact, the practice increases the load of surface materials, which leads to subsidence. Another example comes from land users in Indragiri Hilir who construct gullies around plantation areas; this could worsen subsidence due to loss of carbon dioxide in the drained gullies. Therefore, the land users must be given precise information regarding the status of land subsidence and proper options to deal with the problems wisely.

\section{Matching the Responses of Public Authorities and Land Users}

The response of the public authorities and land users must be consistent throughout the process from awareness to action. The heightened awareness must be followed up with proper and sufficient action. We found that each local government responded to land subsidence in a different manner (see Figure 6). These disparities could be remedied by learning from other areas with similar problems. Semarang City Government should adopt the Jakarta method of allocating zones in spatial detail plans and in strengthening control for groundwater extraction by raising disincentives for development, especially in the coastal area. These measures should be simple to adopt since both cities are located in urban coastal areas. The Jakarta government must strengthen the implementation of zoning regulation to limit land subsidence triggers as well as to select proper zones for economic growth, especially in critical areas. The Indragiri Hilir government must hurry to raise awareness for this problem by recognizing

Public authorities

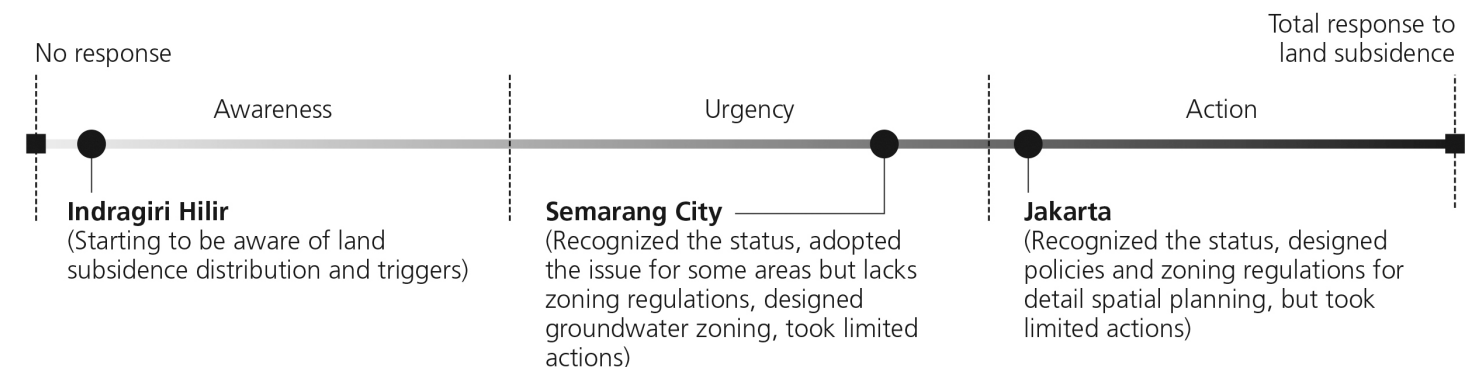

Land users
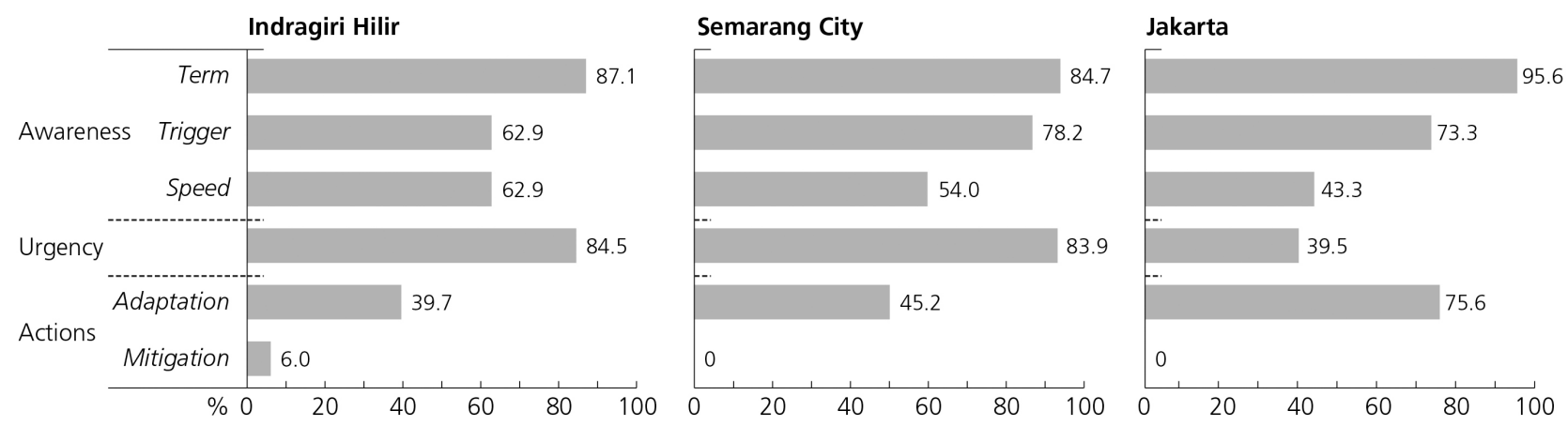

OUU GEO-C\&M 918

Figure 6. Responses of public authorities and land users on land subsidence. 
the status of land subsidence, recognizing about the urgency of the problem and then letting this urgency inspire action. Although the characteristics of the area of Indragiri Hilir are different from the other two areas, some efforts to increase awareness can be adopted. However, the governments must also consider the response of land users to improve the governments' response.

Figure 6 also indicates an inconsistency among land users in taking action after acknowledging the problem and establishing urgency. According to the figure, four fifths of land users are aware of the term land subsidence. More than three-quarters of land users recognized triggers. However, in urban areas, less than three-quarters of them are familiar with the rate at which it can occur. The high degree of awareness is followed by a similarly high sense of urgency among land users in Semarang City, but not in Jakarta. In the rural peat land of Indragiri Hilir, although land subsidence is the slowest here and its effect on daily activities is less substantial than in urban areas, the sense of urgency is the highest among the three locations. We found that the urgency is neither related to the speed of land subsidence in their neighbourhood nor to the effects of land subsidence on daily activities. So, what is the main factor affecting the land users' sense of urgency? Is it the land user's wealth? Is it land status? Or other factors? Regarding action, land users lack the means to mitigate land subsidence although they have already recognized the triggers and speed of land subsidence in their environments. Downs [41] stated that enormous struggles and costly efforts to solve the problems discouraged people from taking action, even though they understood that it was urgent.

Matching the responses of the public authorities and land users, we identified three types of responses to land subsidence: 1) high degree of response from public authorities, but low response of land users, 2) low response of public authorities, but high response of land users and 3) moderate response of both public authorities as well as land users. Since the degree of response between actors is dissimilar, it seems that the public authorities must provide the ability to increase land user's awareness [42]. The actors must also collaborate to solve land subsidence and prevent future problems by raising the sense of urgency, improving policies and action or boosting the self-initiative of affected land users. In urban areas, where land subsidence is mostly caused by groundwater extraction, the government could force groundwater regulations to all groundwater users [43]. In addition, in rural peat land areas, the public authorities must raise the response by strengthening awareness since land users have already started taking action. Based on these conditions, the actors should consider their readiness to respond to land subsidence by starting to give attention to the problem.

\section{Conclusions}

In current Disaster Risk Management, the response of actors in the disaster management cycle is crucial to reduce disaster impact. Baas et al. [19] and $\mathrm{Ku}-$ sumasari et al. [42] show that response during pre-disaster periods will lead public authorities to design proper policies and action, as well as will increase 
people's awareness of potential problems and possible future losses. However, with regard to land subsidence management, the DRM cycle, which was designed for a single shock disaster, appeared less suitable adoption. This is because land subsidence is characterized as a sleeping, or silent, disaster [6], which continuously happens over a long period and beyond a single phase of disaster management. As the impacts of the land subsidence are serious and will be worsening by the combination with climate change [44] [45], the public authorities and land users must select proper means to increase their capacity to adapt to the land subsidence.

In this paper, we find that the response of public authorities and land users to land subsidence varies widely, as is also shown by Holzer [46] and Endo [43]. Our research shows that this could be due to three aspects: the government level, land use association and actors' knowledge of this problem. For the first aspect, we argued that the lower government level shows the lowest response to land subsidence, due to its lack of power to make decisions. Madan [47] shows that this might be expected because of the lack of local government's authority to take immediate decisions on the complex structure of governments. The policy from lower level governments was mainly derived from the higher level government including disaster management, spatial planning and zoning regulation, which highlighted the dependency of local governments within the Indonesian context [48] [49]. The second aspect, the governments' response, seems to be influenced by the intensity of the development and activities, both in urban and rural peat land areas. The response is higher in areas that are more dynamic and denser in residence. The different responses can be seen from international experiences [50] [51]. The need of space for development has been forcing governments to allocate areas to meet fundamental needs such as housing, industry and agriculture, but at the same time, also trying to minimize the impact of land subsidence. Similar governmental reactions can be found in $\mathrm{Hu}$ et al. [52]. The third aspect influencing governmental response to the land subsidence problem concerns their knowledge. We found that a profound lack of knowledge has caused a sort of "ignorance" to land subsidence problems in all case study areas. Land subsidence appears to not be a high priority for public authorities. Since land subsidence is not prioritized, there are no necessary programs and strategies to deal with its impact. Furthermore, we found that the adaptation and mitigation programs to land subsidence were not fully integrated with development policies. This is common as literatures [44] [53] show that in many cities, the governments do not pay much attention to the land subsidence issue.

Based on our analysis of government responses, we argued that governments might benefit from more coherence among the various levels of government. Yet, in their responses to land subsidence, governments could also take benefit if they involved land users in the government agenda to improve the hazard mitigation, as mentioned by Pearce [54].

The typology mentioned requires different interventions and strategies for each type to successfully combat the costs of land subsidence. It has many practical 
applications to create effective forms of land subsidence management, in which both public authorities and land users collaborate. Researchers [28] [42] [54] suggest integrating this into single forms of management, which can be translated into programs that accommodate all interests and diminish limitations. In addition, the quality of the programs will be improved if the involved actors are selected based on their capacities [55].

As land subsidence occurs continuously, the condition of the affected areas can only get worse. In the end, the longer the governments and the land users ignore to the land subsidence, the longer the area and people suffer from the problem, causing the areas to no longer be habitable.

\section{Acknowledgements}

The authors would like to thank Robert Fletcher for his valuable comments in the first draft of this paper as well as Margot Stoete and Ton Markus for the illustration and map. Erlis Saputra would also give his gratitude to Ministry of Research, Technology, and Higher Education of Indonesia for granting him the BPPLN-DIKTI scholarship.

\section{References}

[1] Galloway, D., Jones, D.R. and Ingebritsen, S.E. (1999) Land Subsidence in the United States. US Geological Survey, Reston.

[2] Tripathi, N., Singh, R. and Singh, J. (2009) Impact of Post-Mining Subsidence on Nitrogen Transformation in Southern Tropical Dry Deciduous Forest, India. Environmental Research, 109, 258-266. https://doi.org/10.1016/j.envres.2008.10.009

[3] Chaussard, E., Amelung, F., Abidin, H. and Hong, S. (2013) Sinking Cities in Indonesia: ALOS PALSAR Detects Rapid Subsidence Due To Groundwater and Gas Extraction. Remote Sensing of Environment, 128, 150-161.

https://doi.org/10.1016/j.rse.2012.10.015

[4] Abidin, H.Z., Andreas, H., Gumilar, I., Fukuda, Y., Pohan, Y.E. and Deguchi, T. (2011) Land Subsidence of Jakarta (Indonesia) and Its Relation with Urban Development. Natural Hazards, 59, 1753-1771. https://doi.org/10.1007/s11069-011-9866-9

[5] Lubis, A.M., Sato, T., Tomiyama, N., Isezaki, N. and Yamanokuchi, T. (2011) Ground Subsidence in Semarang-Indonesia Investigated by ALOS-PALSAR Satellite SAR Interferometry. Journal of Asian Earth Sciences, 40, 1079-1088. https://doi.org/10.1016/j.jseaes.2010.12.001

[6] Abidin, H., Andreas, H., Gumilar, I., Sidiq, T.P. and Fukuda, Y. (2013) Land Subsidence in Coastal City of Semarang (Indonesia): Characteristics, Impacts and Causes. Geomatics, Natural Hazards and Risk, 4, 226-240. https://doi.org/10.1080/19475705.2012.692336

[7] Marfai, M.A. and King, L. (2007) Monitoring Land Subsidence in Semarang, Indonesia. Environmental Geology, 53, 651-659. https://doi.org/10.1007/s00254-007-0680-3

[8] Braadbaart, O. and Braadbaart, F. (1997) Policing the Urban Pumping Race: Industrial Groundwater Overexploitation in Indonesia. World Development, 25, 199-210. https://doi.org/10.1016/S0305-750X(96)00102-7

[9] Deverel, S.J. and Rojstaczer, S. (1996) Subsidence of Agricultural Lands in the Sac- 
ramento-San Joaquin Delta, California: Role of Aqueous and Gaseous Carbon Fluxes. Water Resource Research, 32, 2359-2367.

[10] Wosten, J., Ismail, A. and Van Wijk, A. (1997) Peat Subsidence and Its Practical Implications: A Case Study in Malaysia. Geoderma, 78, 25-36. https://doi.org/10.1016/S0016-7061(97)00013-X

[11] Schipper, L.A. and McLeod, M. (2002) Subsidence Rates and Carbon Loss in Peat Soils Following Conversion to Pasture in the Waikato Region, New Zealand. Soil Use and Management, 18, 91-93. https://doi.org/10.1111/j.1475-2743.2002.tb00225.x

[12] Jaenicke, J., Rieley, J., Mott, C., Kimman, P. and Siegert, F. (2008) Determination of the Amount of Carbon Stored in Indonesian Peatlands. Geoderma, 147, 151-158. https://doi.org/10.1016/j.geoderma.2008.08.008

[13] Ehrlich, P.R. and Holdren, J.P. (1971) Impact of Population Growth. Science, 171, 1212-1217. https://doi.org/10.1126/science.171.3977.1212

[14] McGranahan, G., Balk, D. and Anderson, B. (2007) The Rising Tide: Assessing the Risks of Climate Change and Human Settlements in Low Elevation Coastal Zones. Environment and Urbanization, 19, 17-37. https://doi.org/10.1177/0956247807076960

[15] Hartmann, T. and Spit, T. (2014) Capacity Building for the Integration of Climate Adaptation into Urban Planning Processes: the Dutch experience. American Journal of Climate Change, 3, 245-252. https://doi.org/10.4236/ajcc.2014.33023

[16] Hallegatte, S. and Corfee-Morlot, J. (2011) Understanding Climate Change Impacts, Vulnerability and Adaptation at City Scale: An Introduction. Climatic Change, 104, 1-12. https://doi.org/10.1007/s10584-010-9981-8

[17] Ye, S., Xue, Y., Wu, J., Yan, X. and Yu, J. (2015) Progression and Mitigation of Land Subsidence in China. Hydrogeology Journal, 24, 685-693. https://doi.org/10.1007/s10040-015-1356-9

[18] Kokx, A. and Spit, T. (2012) Increasing the Adaptive Capacity in Unembanked Neighborhoods? An Exploration into Stakeholder Support for Adaptive Measures in Rotterdam, the Netherlands. American Journal of Climate Change, 1, 181-193. https://doi.org/10.4236/ajcc.2012.14015

[19] Baas, S., Ramamasy, S., Dey de Pryck, J. and Battista, F. (2008) Disaster Risk Management Systems Analysis: A Guide Book. Environment and Natural Resources Management Series, FAO, Rome.

[20] Freeman, P.K., Martin, L.A., Linnerooth-Bayer, J., Mechler, R., Pflug, G. and Warner, K. (2003) Disaster Risk Management. National Systems for the Comprehensive Management of Disaster Risk, Financial Strategies for Natural Disaster Reconstruction, Inter-American Development Bank, IDB, Washington, DC.

[21] Seppänen, H. and Virrantaus, K. (2015) Shared Situational Awareness and Information Quality in Disaster Management. Safety Science, 77, 112-122. https://doi.org/10.1016/j.ssci.2015.03.018

[22] Chopra, B.K. and Venkatesh, M.D. (2015) Dealing with Disasters: Need for Awareness and Preparedness. Medical Journal Armed Forces India, 71, 211-213. https://doi.org/10.1016/j.mjafi.2015.06.019

[23] Stork, S.V. and Sneed, M. (2002) Houston-Galveston Bay Area, Texas, from Space: A New Tool for Mapping Land Subsidence. US Department of the Interior. US Geological Survey.

[24] Blaikie, P., Cannon, T., Davis, I. and Wisner, B. (2010) At Risk: Natural Hazards, People's Vulnerability and Disasters. Routledge, New York. 
[25] Tang, Z., Brody, S.D., Quinn, C., Chang, L. and Wei, T. (2010) Moving from Agenda to Action: Evaluating Local Climate Change Action Plans. Journal of Environmental Planning and Management, 53, 41-62. https://doi.org/10.1080/09640560903399772

[26] Gaillard, J. and Mercer, J. (2013) From Knowledge to Action: Bridging Gaps in Disaster Risk Reduction. Progress in Human Geography, 37, 93-114. https://doi.org/10.1177/0309132512446717

[27] Ha, H., Fernando, R.L.S. and Mahmood, A. (2015) Disaster Management in Asia: Lessons Learned and Policy Implications. In: Ha, H., Fernando, R.L.S. and Mahmood, A., Eds., Strategic Disaster Risk Management in Asia, Springer, India, 221226. https://doi.org/10.1007/978-81-322-2373-3_15

[28] Djalante, R., Holley, C. and Thomalla, F. (2011) Adaptive Governance and Managing Resilience to Natural Hazards. International Journal of Disaster Risk Science, 2, 1-14. https://doi.org/10.1007/s13753-011-0015-6

[29] Kotter, J.P. (2008) A Sense of Urgency. Harvard Business Press, Boston.

[30] Page, S.E., Siegert, F., Rieley, J.O., Boehm, H.V., Jaya, A. and Limin, S. (2002) The Amount of Carbon Released from Peat and Forest Fires in Indonesia during 1997. Nature, 420, 61-65. https://doi.org/10.1038/nature01131

[31] Abidin, H.Z., Gumilar, I., Andreas, H., Murdohardono, D. and Fukuda, Y. (2013) On Causes and Impacts of Land Subsidence in Bandung Basin, Indonesia. Environmental Earth Sciences, 68, 1545-1553. https://doi.org/10.1007/s12665-012-1848-z

[32] Phien-Wej, N., Giao, P. and Nutalaya, P. (2006) Land subsidence in Bangkok, Thailand. Engineering Geology, 82, 187-201. https://doi.org/10.1016/j.enggeo.2005.10.004

[33] Alam, M. (1996) Subsidence of the Ganges-Brahmaputra Delta of Bangladesh and Associated Drainage, Sedimentation and Salinity Problems. In: Milliman, J. and Haq, B.U., Eds., Anonymous Sea-Level Rise and Coastal Subsidence: Causes, Consequences, and Strategies. Springer, Berlin, 169-192. https://doi.org/10.1007/978-94-015-8719-8_9

[34] Milliman, J. and Haq, B.U. (1996) Sea-Level Rise and Coastal Subsidence: Causes, Consequences, and Strategies. Springer, Berlin. https://doi.org/10.1007/978-94-015-8719-8

[35] Van der Meij, J. and Minnema, B. (1999) Modelling of the Effect of a Sea-Level Rise and Land Subsidence on the Evolution of the Groundwater Density in the Subsoil of the Northern Part of the Netherlands. Journal of Hydrology, 226, 152-166. https://doi.org/10.1016/S0022-1694(99)00150-X

[36] Warren, J.P., Jones, L.L., Lacewell, R.D. and Griffin, W.L. (1975) External Costs of Land Subsidence Houston-Baytown Area. American Journal of Agricultural Economics, 57, 450-455. https://doi.org/10.2307/1238407

[37] Hu, Z., Hu, F., Li, J. and Li, H. (1997) Impact of Coal Mining Subsidence on Farmland in Eastern China. International Journal of Surface Mining, Reclamation, and Environment, 11, 91-94. https://doi.org/10.1080/09208119708944066

[38] Hu, B., Zhou, J., Xu, S., Chen, Z., Wang, J., Wang, D., Wang, L., Guo, J. and Meng, W. (2013) Assessment of Hazards and Economic Losses Induced by Land Subsidence in Tianjin Binhai New Area from 2011 to 2020 Based on Scenario Analysis. Natural Hazards, 66, 873-886. https://doi.org/10.1007/s11069-012-0530-9

[39] Qureshi, A.M., Butt, M. and Khan, O.M. (2006) The Role of GIS and Public Awareness for Disaster Management. International Conference on Advances in Space Technologies, Islamabad, 2-3 September 2006, 37-42.

[40] King, D. (2000) You're on Your Own: Community Vulnerability and the Need for 
Awareness and Education for Predicatable Natural Disasters. Journal of Contingencies and Crisis Management, 8, 223-228. https://doi.org/10.1111/1468-5973.00143

[41] Downs, A. (1972) Up and down with Ecology-the Issue-Attention Cycle. The Public Interest, 28, 38-50.

[42] Kusumasari, B., Alam, Q. and Siddiqui, K. (2010) Resource Capability for Local Government in Managing Disaster. Disaster Prevention and Management, 19, 438-451. https://doi.org/10.1108/09653561011070367

[43] Endo, T. (2011) Sinking Cities and Governmental Action: Institutional Responses to Land Subsidence in Osaka and Bangkok. In: Taniguchi, M., Ed., Groundwater and Subsurface Environments: Human Impacts in Asian Coastal Cities, Springer, Berlin, 271-288. https://doi.org/10.1007/978-4-431-53904-9_14

[44] Wang, J., Gao, W., Xu, S. and Yu, L. (2012) Evaluation of the Combined Risk of Sea Level Rise, Land Subsidence, and Storm Surges on The Coastal Areas of Shanghai, China. Climatic Change, 115, 537-558. https://doi.org/10.1007/s10584-012-0468-7

[45] Nicholls, R.J. (1995) Coastal Megacities and Climate Change. GeoJournal, 37, 369379. https://doi.org/10.1007/BF00814018

[46] Holzer, T.L. (1989) State and Local Response to Damaging Land Subsidence in United States Urban Areas. Engineering Geology, 27, 449-466. https://doi.org/10.1016/0013-7952(89)90041-0

[47] Madan, A. (2015) Institutional Framework for Preparedness and Response of Disaster Management Institutions from National to Local Level in India with Focus on Delhi. International Journal of Disaster Risk Reduction, 14, 545-555. https://doi.org/10.1016/j.ijdrr.2015.10.004

[48] Kusumasari, B. and Alam, Q. (2012) Bridging the Gaps: The Role of Local Government Capability and the Management of a Natural Disaster in Bantul, Indonesia. Natural Hazards, 60, 761-779. https://doi.org/10.1007/s11069-011-0016-1

[49] Hudalah, D. and Woltjer, J. (2007) Spatial Planning System in Transitional Indonesia. International Planning Studies, 12, 291-303. https://doi.org/10.1080/13563470701640176

[50] Frazier, T.G., Walker, M.H., Kumari, A. and Thompson, C.M. (2013) Opportunities and Constraints to Hazard Mitigation Planning. Applied Geography, 40, 52-60. https://doi.org/10.1016/j.apgeog.2013.01.008

[51] Lall, S.V. and Deichmann, U. (2012) Density and Disasters: Economics of Urban Hazard Risk. The World Bank Research Observer, 27, 74-105. https://doi.org/10.1093/wbro/lkr006

[52] Hu, R., Yue, Z., Wang, L. and Wang, S. (2004) Review on Current Status and Challenging Issues of Land Subsidence in China. Engineering Geology, 76, 65-77. https://doi.org/10.1016/j.enggeo.2004.06.006

[53] Rodolfo, K.S. and Siringan, F.P. (2006) Global Sea-Level Rise Is Recognized, But Flooding from Anthropogenic Land Subsidence Is Ignored Around Northern Manila Bay, Philippines. Disasters, 30, 118-139. https://doi.org/10.1111/j.1467-9523.2006.00310.x

[54] Pearce, L. (2003) Disaster Management and Community Planning, and Public Participation: How to Achieve Sustainable Hazard Mitigation. Natural Hazards, 28, 211 228. https://doi.org/10.1023/A:1022917721797

[55] Hartmann, T. and Spit, T. (2015) Legitimizing Differentiated Flood Protection Levels-Consequences of The European Flood Risk Management Plan. Environmental Science \& Policy, 55, 361-367. https://doi.org/10.1016/j.envsci.2015.08.013 
Submit or recommend next manuscript to SCIRP and we will provide best service for you:

Accepting pre-submission inquiries through Email, Facebook, LinkedIn, Twitter, etc. A wide selection of journals (inclusive of 9 subjects, more than 200 journals)

Providing 24-hour high-quality service

User-friendly online submission system

Fair and swift peer-review system

Efficient typesetting and proofreading procedure

Display of the result of downloads and visits, as well as the number of cited articles Maximum dissemination of your research work

Submit your manuscript at: http://papersubmission.scirp.org/

Or contact ajcc@scirp.org 